\title{
Substrate in the emergence and initial growth of seedlings of Caesalpinia pulcherrima
}

\author{
Magnólia Martins Alves ${ }^{*}$ Edna Ursulino Alves ${ }^{2}$ \\ Luciana Rodrigues de Araújo $^{2}$ Maria de Lourdes dos Santos Lima ${ }^{2}$
}

${ }^{1}$ Programa de Pós-graduação em Agronomia, Centro de Ciências Agrárias (CCA), Universidade Federal da Paraíba (UFPB), 58397-000, Areia, PB, Brasil. E-mail: magecologia@hotmail.com. "Corresponding author.

${ }^{2}$ Departamento de Fitotecnia e Ciências Ambientais, Universidade Federal da Paraíba (UFPB), Areia, PB, Brasil.

ABSTRACT: Caesalpinia pulcherrima is an exotic species belongs to the Fabaceae family commonly known as flamboyant-mirim, and widely used for urban forestry. This study aimed to evaluate the effect of different substrates on the emergence and early seedlings growth of $\boldsymbol{C}$. pulcherrima. The experiment was conducted in a greenhouse belonging to the Centro de Ciências Agrárias, Universidade Federal da Paraiba. The experimental design was completely randomized and treatments had 14 substrates: sand, vegetable soil, vermiculite, wood dust, carbonized rice straw, vegetable soil + sand 1:1, sand + wood dust 1:1, sand + carbonized rice straw 1:1, earth + wood dust 1:1, vegetable soil + carbonized rice straw 1:1, vermiculite + sand $1: 1$, vermiculite + wood dust $1: 1$, vermiculite + earth $1: 1$ and vermiculite + carbonized rice straw 1:1. Evaluation of the effect of the treatments was through the following determinations: percentage of emergency, first count, index of germination speed, length and dry weight of roots and shoots. The vermiculite, vegetable soil + sand 1:1, vermiculite + sand 1:1, vermiculite + saw dust 1:1, are suitable for emergence and early growth of seedlings of Caesalpinia pulcherrima. Substrates saw dust and carbonized rice straw were responsible for the worst performers on emergence and seedling development.

Key words: Flamboyant mirim, ornamental species, seeds, vigor.

Substrato na emergência e crescimento inicial de plântulas de Caesalpinia pulcherrima

RESUMO: Caesalpinia pulcherrima é uma espécie exótica que pertence à família Fabaceae vulgarmente conhecida como flamboyant-mirim, e amplamente utilizadas para arborização urbana. O objetivo do trabalho foi avaliar o efeito de diferentes substratos sobre a emergência e crescimento inicial de plântulas de $\boldsymbol{C}$. pulcherrima. O experimento foi conduzido em casa de vegetação pertencente ao Centro de Ciências Agrárias da Universidade Federal da Paraiba. O delineamento experimental foi inteiramente casualizado e os tratamentos foram compostos por 14 substratos: areia, terra vegetal, vermiculita, pó de madeira, palha de arroz carbonizada, areia + terra vegetal 1:1, areia + pó de madeira 1:1, areia + palha de arroz carbonizada 1:1, terra vegetal + pó de madeira 1:1, terra vegetal + palha de arroz carbonizada 1:1, vermiculita + areia 1:1, vermiculita + pó de madeira 1:1, vermiculita + terra vegetal 1:1 e vermiculita + palha de arroz de carbonizada 1:1. A avaliação do efeito dos tratamentos foi através das seguintes determinações: porcentagem de emergência, primeira contagem, indice de velocidade de emergência, comprimento e massa seca de raizes e parte aérea. A vermiculita, terra vegetal + areia 1:1, vermiculita + areia 1:1, vermiculita + pó de madeira 1:1, são adequados para a emergência e crescimento inicial de mudas de Caesalpinia pulcherrima. Os substratos pó de madeira e palha de arroz carbonizada foram os responsáveis pelos piores desempenhos na emergência e desenvolvimento de plântulas. Palavras-chave: Flamboyant mirim, espécie ornamental, sementes, vigor.

\section{INTRODUCTION}

Caesalpinia pulcherrima (L.) Sw. is native to Central America and was introduced in Brazil, where it developed very well by adapting to soil and climatic conditions of the country. It belongs to the family Fabaceae, subfamily Caesalpinioideae, and can be known asl poinciana-anã, and flamboyant mirim, reaching 3 to $4 \mathrm{~m}$ time due to the beauty of its flowers. This species has been widely used in landscaping in general and also in urban forestry, and the seeds as the main means of propagation (LORENZI, 2009).
Studies have shown that its seed dormancy feature, of the physical type which can be overcome by mechanical scraping (OLIVEIRA et al., 2010) and germinate successfully over a wide temperature range, varied from 20 to $40^{\circ} \mathrm{C}$ (FONSECA \& JACOBI, 2011). The first method for obtaining information on species of seed plants, is related to germination, which is influenced by a number of intrinsic and environmental conditions of the extrinsic seed. Each substrate had important factors that influenced the percentage uniformity and speed germination, resulting in more vigorous seedlings and reduced production costs (CARVALHO \& NAKAGAWA, 2012). 
There are factors that affect germination and development of species such as substrate, which is one of the most important influencing in the root developing system and providing nutrients for plants (NOGUEIRA et al., 2012). The substrate is one of the most important external factors in the development of seedlings in the nursery, influencing both seed germination and the growth of seedlings, which favors its production in a short period of time at low cost (DUTRA et al., 2012).

Thus, the choice of the substrate must be taken into account the size of the seed, its requirement with respect to moisture and the ease it provides for the development and evaluation of seedlings (BRASIL, 2009). Therefore, it is extremely important to study substrates for the propagation of forest species, in order to identify the one that provides the best emergency and early seedling development. Based on the above, the objective was to evaluate the effect of different substrates on the emergence and early growth of seedlings of $\boldsymbol{C}$. pulcherrima.

\section{MATERIALS AND METHODS}

The research was conducted in greenhouse belonging to the Seed Analysis Laboratory, Department of Plant and Environmental Sciences, Centre of Agricultural Sciences, (CCA) Universidade Federal de Paraíba, (UFPB) in Areia, PB.

Fruits of $\boldsymbol{C}$. pulcherrima trees were harvested directly from trees placed in CCA - UFPB in Areia, $\mathrm{PB}$, from ten mother plants, with minimum distance between them of 20 meters, good plant appearance and rounded crown. Fruits were taken to the laboratory for processing, which consisted of manual opening of the pods to obtain the seeds. After being subjected to scarification with sandpaper in the region opposite to the hilum, the seeds were sown in plastic trays with dimensions of $49 \times 33 \times 7 \mathrm{~cm}$ using the following substrates: sand, vegetable soil, vermiculite, sawdust, carbonized rice straw, vegetable soil + sand 1:1, sand + sawdust 1:1, sand + carbonized rice straw $1: 1$, vegetable soil + sawdust $1: 1$, vegetable soil + carbonized rice straw $1: 1$, vermiculite + sand $1: 1$, vermiculite + sawdust $1: 1$, vermiculite + ground $1: 1$, vermiculite + carbonized rice straw $1: 1$, at a depth of $1 \mathrm{~cm}$. To keep moisture from the substrate, it were daily watered e with manual sprinklers and to evaluate the effect of the treatments it was determined the following variables:

Emergency - 100 seeds were used for each treatment, divided into four replicates of 25 , counts of number of seedlings are started at six and lasted until 21 days after sowing, considering as evaluation criteria, seedlings with the cotyledons above the substrate, with the results expressed in percentage.

Emergency first count - corresponding to the cumulative percentage of normal seedlings, with values recorded on the sixth day after the start of the test.

Speed of emergence index (IVE) - daily counts of normal seedlings emerged during 21 days, whose index was calculated according to the formula proposed by MAGUIRE (1962).

Length and mass of root/shoot seedling - 21 days after sowing, the normal seedlings were removed from the trays, and the cotyledons removed parts (main root and shoot) measured with the aid of ruler graduated in centimeters; parties seedling (roots and shoots) before measures were put in Kraft paper bags and dried in an oven at $65^{\circ} \mathrm{C}$ for 48 hours and the results were expressed in $\mathrm{g} \mathrm{cm}^{-1}$ seedlings, respectively.

Experimental design and statistical analysis - the design was completely randomized and the data subjected to analysis of variance by F test, with means compared by the Scott - Knott test at $5 \%$ probability.

\section{RESULTS AND DISCUSSION}

Among the substrates we observed a significant difference, if noting that the vermiculite $(96 \%)$; vegetable soil + sand $(92 \%)$; vermiculite and sand (94\%); and vermiculite + saw dust (96\%) had the highest percentages seedling emergence of C. pulcherrima. With respect to the first count and speed of emergence index these same treatments provided the best results (Table 1). Probably because the vermiculite had the capacity to absorb up to five times the volume of water as it is composed of larger particles, lower density or lower degree of compaction therefore, greater facilities for seedling emergence (FILGUEIRA, 2008).

The speed and uniformity of germination characteristics are desirable, since the longer the seedling remains in the early stages of development, it is more subjected to adverse environmental conditions, including susceptible to fungi, often present in the seeds (BOTELHO et al., 2008). The substrates washed sand, vermiculite, topsoil, bioclone $^{\circledR}$ and bioplant ${ }^{\circledR}$ pure or mixed seeds of Erythrina velutina Willd. expressed their maximum germination potential due to the ideal conditions of moisture and aeration (ALVES et al., 2008).

For the seedling emergence of C. pulcherrima likely these substrates have characteristics necessary for a good germination performance such as porosity and sterility since 
Table 1 - Emergency and first count of germination speed index (IVE) of Caesalpinia pulcherrima seedlings in a different function substrates.

\begin{tabular}{|c|c|c|c|}
\hline \multirow{2}{*}{ Treatments } & Emergency & First Count & \multirow{2}{*}{ IVE } \\
\hline & \multicolumn{2}{|c|}{ 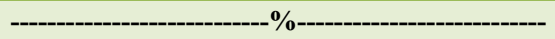 } & \\
\hline Sand & $84 b$ & $83 b$ & $3.25 b$ \\
\hline Vegetable soil & $61 d$ & $48 \mathrm{e}$ & $2.00 \mathrm{~d}$ \\
\hline Vermiculite & $96 a$ & $94 \mathrm{a}$ & $3.90 \mathrm{a}$ \\
\hline Wood dust & $17 \mathrm{e}$ & $21 \mathrm{f}$ & $0.50 \mathrm{e}$ \\
\hline Carbonized rice straw & $24 \mathrm{e}$ & $4 g$ & $0.50 \mathrm{e}$ \\
\hline Vegetable soil + sand $1: 1$ & $92 \mathrm{a}$ & $84 b$ & $3.00 \mathrm{c}$ \\
\hline Sand + wood dust $1: 1$ & $77 \mathrm{c}$ & $75 c$ & $3.00 \mathrm{c}$ \\
\hline Sand + carbonized rice straw $1: 1$ & $83 b$ & $79 \mathrm{c}$ & $2.75 \mathrm{c}$ \\
\hline Vegetable soil + wood dust $1: 1$ & $73 \mathrm{c}$ & $64 d$ & $2.25 \mathrm{~d}$ \\
\hline Vegetable soil + carbonized rice straw 1:1 & $77 \mathrm{c}$ & $63 d$ & $2.50 \mathrm{~d}$ \\
\hline Vermiculite + sand $1: 1$ & $94 \mathrm{a}$ & $95 \mathrm{a}$ & $4.00 \mathrm{a}$ \\
\hline Vermiculite + wood dust $1: 1$ & $96 a$ & $91 \mathrm{a}$ & $3.75 \mathrm{a}$ \\
\hline Vermiculite + vegetable soil $1: 1$ & $87 \mathrm{~b}$ & $82 b$ & $3.00 \mathrm{c}$ \\
\hline Vermiculite + carbonized rice straw $1: 1$ & $85 b$ & 76 & $2.75 \mathrm{c}$ \\
\hline $\mathrm{CV}(\%)$ & 8.27 & 7.75 & 15.24 \\
\hline
\end{tabular}

Means followed by same letter in column do not differ statistically among themselves by the Scott Knott test at 5\% significance.

good porosity that allows movement of water and air in it, which promotes germination (ALVES et al., 2008). The use of sand substrates, vermiculite and commercial hortimix (1:1:1) afforded mulungu (E. velutina) Willd seedlings to developemore and better quality (GUIMARÃES et al., 2011). As for emergency data, first count and speed of emergency in powdered wood substrates, and carbonized rice straw reported a significant reduction. Thus, we perceive that these substrates showed no ideal moisture and oxygen conditions, since the seeds did not express its maximum potential germination (ALVES et al., 2011). In a research by PINTO et al. (2011) the rate of speed of seedling emergence of Mimosa caesalpiniifolia Benth was higher on vermiculite, coconut fiber and hortimix. Mixtures of vermiculite, coconut fiber and organic compost, coconut fiber and organic compound were favorable to germination and seedling emergence of $\mathbf{M}$. caesalpiniifolia Benth (NOGUEIRA et al., 2012).

Analyzing the data in table 2 it appears that the seedlings of $\boldsymbol{C}$. pulcherrima werevmost vigorous (higher primary root length) on vermiculite, vermiculite + vegetable soil, with mean values of 15.90 and $14,71 \mathrm{~cm}$, respectively. Regarding the shoot length, the highest values were observed when using the vermiculite and vegetable soil + sand, vermiculite and vermiculite + vegetable soil possibly because it met all the requirements for rapid and uniform emergence, as well as a satisfactory initial growth
(ALVES et al., 2008). According to MARTINS et al. (1999), emerging seedlings can quickly become less vulnerable to adverse environmental conditions by spending less time in the early stages of development. Between this and that besides providing good results, vermiculite is easy to handle, inorganic, neutral and light, why has been widely used for forest species (FIGLIOLIA et al., 1993).

Although the data in table 2, it can be observed that the lower results of primary root length and shoot were obtained using the powder substrate of wood and carbonized rice straw. For seedling growth it was was considered too slow, not being observed difference between the initial and final phase of the experiment, which allowed little gain in dry mass of the same. Seedlings originated from seeds of substrates washed sand, vermiculite 1:1, 3:1 washed sand, vermiculite, bioclone ${ }^{\circledR}$ and bioplant ${ }^{\circledR}$ provided longer roots of $\boldsymbol{E}$. velutina Willd., (ALVES et al., 2008).

With the dry mass of roots, the highest values were obtained when the following substrates was used: sand, vermiculite, vegetable soil + sand, sand + carbonized rice straw and vermiculite + sand, while the lowest values were observed in seedlings grown from seeds of powder wood substrates and carbonized rice straw. As dry mass of the aerial part of seedlings were originated from seeds sown in sandy substrates, vermiculite, vegetable soil + sand $1: 1$ observed positive influence by higher contents. In 
Table 2 - Length and dry weight of roots and shoots of seedlings of Caesalpinia pulcherrima, for different substrates.

\begin{tabular}{|c|c|c|c|c|}
\hline \multirow{2}{*}{ Treatments } & \multicolumn{2}{|c|}{-----------------Lenght (cm) ---------------- } & \multicolumn{2}{|c|}{---------------Dry Mass (g)-------------' } \\
\hline & Root & Shoot & Root & Shoot \\
\hline Sand & $7.28 \mathrm{~d}$ & $13.91 b$ & $0.032 \mathrm{a}$ & $0.125 \mathrm{a}$ \\
\hline Vegetable soil & $5.85 \mathrm{~d}$ & $8.36 \mathrm{~d}$ & $0.087 \mathrm{a}$ & $0.067 \mathrm{~b}$ \\
\hline Vermiculite & $15.90 \mathrm{a}$ & $15.68 \mathrm{a}$ & $0.035 \mathrm{a}$ & $0.164 \mathrm{a}$ \\
\hline Wood dust & $1.30 \mathrm{e}$ & $1.53 \mathrm{e}$ & $0.002 \mathrm{c}$ & $0.017 \mathrm{c}$ \\
\hline Carbonized rice straw & $1.38 \mathrm{e}$ & $1.78 \mathrm{e}$ & $0.005 \mathrm{c}$ & $0.017 \mathrm{c}$ \\
\hline Vegetable soil + sand $1: 1$ & $11.84 b$ & $15.10 \mathrm{a}$ & $0.042 \mathrm{a}$ & $0.146 a$ \\
\hline Sand + wood dust $1: 1$ & $6.34 \mathrm{~d}$ & $9.12 \mathrm{~d}$ & $0.019 b$ & $0.084 \mathrm{~b}$ \\
\hline Sand + carbonized rice straw $1: 1$ & $9.90 \mathrm{c}$ & $10.08 \mathrm{c}$ & $0.028 \mathrm{a}$ & $0.077 b$ \\
\hline Vegetable soil + wood dust $1: 1$ & $9.31 \mathrm{c}$ & $11.16 \mathrm{c}$ & $0.021 b$ & $0.087 \mathrm{~b}$ \\
\hline Vegetable soil + carbonized rice straw $1: 1$ & $10.74 \mathrm{c}$ & $11.16 \mathrm{c}$ & $0.018 b$ & $0.081 b$ \\
\hline Vermiculite + sand $1: 1$ & $11.84 b$ & $14.16 b$ & $0.031 \mathrm{a}$ & $0.107 \mathrm{~b}$ \\
\hline Vermiculite + wood dust $1: 1$ & $12.85 b$ & $14.01 b$ & $0.019 b$ & $0.103 b$ \\
\hline Vermiculite + vegetable soil 1:1 & $14.71 \mathrm{a}$ & $13.92 b$ & $0.025 b$ & $0.097 \mathrm{~b}$ \\
\hline Vermiculite + carbonized rice straw $1: 1$ & $11.40 \mathrm{~b}$ & $13.51 b$ & $0.001 \mathrm{c}$ & $0.008 \mathrm{c}$ \\
\hline $\mathrm{CV}(\%)$ & 9.16 & 6.94 & 33.15 & 35.92 \\
\hline
\end{tabular}

Means followed by same letter in column do not differ statistically among themselves by the Scott Knott test at 5\% significance.

seeds subjected to dust wood substrates and carbonized rice straw, the lowest values of length and dry weight of roots and shoots occurred. Most treatments that yielded the highest values of seedling length when associated with vermiculite were also responsible for the maximum values of dry mass of roots and shoots. In turn, COSTA et al. (2005) had higher dry matter content of roots and shoots of seedlings of Genipa americana $\mathrm{L}$. substrates in black vegetable soil + manure $(2: 1)$ and black earth + carbonized rice hull + manure $(1: 2: 1)$. Dry weight of roots had the highest values in the substrates (topsoil + manure and topsoil + sand, both 3:1, respectively) on species Zizyphus joazeiro Mart. (BRAGA JÚNIOR et al., 2010).

In relation to total dry the mass seedlings of M. caesalpiniifolia Benth the matter higher values were obtained in the treatment for more coconut fiber (1:1) but not differed statistically from sand treatments and coconut fiber (PINTO et al., 2011). Vermiculite, coconut fiber and hortimix (commercial) provided higher values of dry mass stalk of seedlings of M. Caesalpiniifolia Benth (NOGUEIRA et al., 2012). Seedlings of Peltophorum dubium (Spreng.) taken from bioplant ${ }^{\circledR}+$ and bagasse $^{\circledR}$ (3:1) were the substrates with higher content of dry mass of roots and shoots (DUTRA et al., 2012). With the dry mass of the air part of Adenanthera pavonina L. seeds when sown in rice hulls $(0.089 \mathrm{~g})$ promoted the highest content (ALVES et al., 2015).

\section{CONCLUSION}

The vermiculite, vegetable soil + sand $1: 1$, vermiculite + sand $1: 1$, vermiculite + saw dust $1: 1$, are suitable for emergence and early growth of seedlings of Caesalpinia pulcherrima. The substrates saw dust and rice straw were responsible for the worst performers on emergence and seedling development.

\section{ACKNOWLEDGEMENTS}

Authors would like to thank the Seed Analysis Laboratory, "Center for Agrarian Sciences of Paraiba" municipality of Areia (CCA), Universidade Federal da Paraiba (UFPB).

\section{REFERENCES}

ALVES, E.U. et al. Substrates for seedling emergence tests and seed vigor of Erythrina velutina Willd., Fabaceae. Semina: Ciências Agrárias, Londrina, v.29, n.1, p.69-82, 2008. Available from: <http://www.scielo.br/scielo.php?00009414154366201000040001000002>. Accessed: Nov. 25, 2014. doi: 10.5433/1679-0359.2008v29n1p69.

ALVES, E.U. et al. Emergence and initial growth of seedlings of Peltophorum dubium (Spreng.) Taubert under different substrates. Revista Ciência Agronômica, Fortaleza, v.42, n.2, p.439-447, 2011. Available from: <http://www.scielo.br/pdf/rca/v42n2/ a25v42n2.pdf>. Accessed: Nov. 25, 2014. doi: 195318915025.

ALVES, M.M. et al. Initial seedling growth of Adenanthera pavonina L. as a function of different substrates. Revista Ciência Agronômica, Fortaleza, v.46, n.2, p.352-357, 2015. 
Available from: <http://www.ccarevista.ufc.br/seer/index.php/ ccarevista/article/view/3826/1181>. Accessed: July 10, 2015. doi: $10.5935 / 1806-6690.20150014$

BOTELHO, L.S. et al. Fungi associated with the seeds of ipê-amarelo (Tabebuia serratifolia) and ipê-roxo (Tabebuia impetiginosa): incidence, effect on germination and transmission to the seedlings. Summa Phytopathol, Botucatu, v.34, n.4, p.343348, 2008. Available from: <http://www.scielo.br/scielo.php?pi $\mathrm{d}=\mathrm{S} 0100-54052008000400008>$. Accessed: Nov. 22, 2014. doi: $10.1590 / \mathrm{S} 0100-54052008000400008$

BRASIL. Ministério da Agricultura, Pecuária e Abastecimento. Regras para análise de sementes. Brasília: Secretaria de Defesa Agropecuária/MAPA/ACS, 2009. 395p.

BRAGA JÚNIOR, J.M. et al. Emergence of seedlings of Zizyphus joazeiro Mart (Rhamnaceae) as a function of substrates. Revista Árvore, Viçosa, v.34, n.4, p.609-616, 2010. Available from: <http://www.scielo.br/scielo.php?pid $=$ S0100-67622010000400005 $>$. Accessed: Nov. 25, 2014. doi: $10.1590 / \mathrm{S} 0100-67622010000400005$.

CARVALHO, N.M.; NAKAGAWA, J. Sementes: ciência, tecnologia e produção. 5.ed. FUNEP: Jaboticabal, 2012. 590p.

COSTA, M.C. et al. Substrates for production seedlings of jenipapo (Genipa americana L.). Pesquisa Agropecuária Tropical, Goiânia, v.35, n.1, p.19-24, 2005. Available from: <http://www. revistas.ufg.br/index.php/pat/article/view/2280>. Accessed: Nov. 25, 2014. doi: 10.6008\%2FESS2237-9290.2011.001.0004.

DUTRA, T.R. et al. Emergence and initial growth of the canafístula in different substrates and methods of overcoming dormancy. Revista Caatinga, Mossoró, v.25, n.2, p.65-71, 2012. Available from: <http://periodicos.ufersa.edu.br/revistas/index.php/sistema/ article/view/2243>. Accessed: Accessed: Nov. 20, 2014

FILGUEIRA, F.A.R. Novo manual de olericultura: agrotecnologia moderna na produção e comercialização de hortaliças. 3.ed. Viçosa: UFV, 2008. 421p.

FIGLIOLIA, M.B. et al. Análise de sementes. In: AGUIAR, I.B. et al. (Coords.). Sementes florestais tropicais. Brasília: ABRATES, 1993. p.137-174
FONSECA, N.G.; JACOBI, C.M. Germination performance of the invasive Leucaena leucocephala (Lam.) de Wit. And comparison with Caesalpinia ferrea Mart. ex. Tul. and Caesalpinia pulcherrima (L.) Sw. (Fabaceae). Acta Botanica Brasilica, Belo Horizonte v.25, n.1, p.191-197, 2011. Available from: <http:// www.scielo.br/scielo.php>. Accessed: Nov. 25, 2014. doi: 10.1590/ S0102-33062011000100022.

GUIMARÃES, I.P. et al. Effect of different substrates on emergence and vigor of mulungu seedlings. Revista Bioscience Journal, Uberlândia, v.27, n.6, p.932-938, 2011. Available from: $<$ http://www.seer.ufu.br/index.php/biosciencejournal/article/ view/12306/8121>. Accessed: Oct. 20, 2014.

LORENZI, H. Árvores brasileiras: manual de identificação e cultivo de plantas arbóreas nativas do Brasil. Nova Odessa: Plantarum, 2009. V.2, 368p.

MAGUIRE, J.D. Speed of germination-aid in selection and evaluation for seedling emergence and vigor. Crop Science, Madson, v.2, n.2, p.176-177, 1962.

MARTINS, C.C. et al. Effect of seed position on substrate and initial seedling growth of palmito-vermelho (Euterpe espiritosantensis Fernandes - Palmae). Revista Brasileira de Sementes, Londrina, v.21, n.1, p.164-173, 1999. Available from: <http://www.abrates. org.br/artigos-publicados>. Accessed: Nov. 25, 2014

NOGUEIRA, N.W. et al. Emergence and initial development of seedlings of Mimosa caesalpiniifolia Benth. depending on different substrates. Revista Agro@mbiente On-line, Mossoró, v.6, n.1, p.17-24, 2012. Available from: <http://revista.ufrr.br/ agroambiente/article/view/695/685>. Accessed: Nov. 25, 2014 doi: 10.18227/1982-8470ragro.v6i1.695. Accessed: Nov. 25, 2014.

OLIVEIRA, L.M. et al. Treatments pre-germination on Caesalpinia pulcherrima (L) Sw seeds. - Leguminosae. Revista Caatinga, Mossoró, v.23, n.1, p.71-76, 2010. Available from: <http://www. redalyc.org/articulo.oa?id=237117582011>. Accessed: Nov. 25, 2014.

PINTO, J.R.S. et al. Different types of substrates in the early development of Mimosa caesalpiniifolia Benth. Revista Verde de Agroecologia e Desenvolvimento Sustentável, Mossoró, v.6, n.3, p.180-185, 2011. Available from: <http://www.gvaa.com.br/revista/ index.php/RVADS/article/view/799/710>. Accessed: Nov. 25, 2014. 